\title{
TERMOVISION AND ELECTRICITY CAPACITANCE MEASUREMENTS AS A EVALUATION OF A HELICOPTER ROTOR'S BLADES DELAMINATION
}

\author{
OCENA ROZWARSTWIENIA LOPAT WIRNIKÓW \\ ŚMIGLOWCÓW NA PODSTAWIE POMIARÓW \\ POJEMNOŚCI ELEKTRYCZNEJ ORAZ TEMPERATURY \\ MIERZONEJ METODĄ TERMOWIZYJNĄ
}

\author{
Andrzej Gębura, Michał Poradowski \\ Instytut Techniczny Wojsk Lotniczych \\ e-mail: andrzej.gebura@itwl.pl
}

\begin{abstract}
The article presents essential elements reached during investigations of heat section of rotor blades which have been done in AFIT. The investigations were related to a valuation of helicopter's rotor blades delamination. They used a method of thermal field measurement as well as a electricity capacitance between an airframe and a heat element of the installation. A suggestion of such measurements appeared during the disassembly of rotor blade heat sections when some local unglue of heat element's tape from the structure of blade's heating pack has seen. Spots nearby separation of adhesive are a potential area of a local temperature increase, both the electric heating element and the mechanical structure of the blade. This is especially dangerous for composite structures. Overheated composite structures characterized by reduced flexibility and becomes prone to cracking. Therefore, the possibility of non-invasive monitoring adhesive spots, without removing the blades would be particularly useful.
\end{abstract}

Keywords: delamination of a composite helicopter blades, heat sections of rotor blades, an anti-icing electric heating, an isolation of rotor blade's heating pack, electricity capacity of an isolation.

Streszczenie: Artykut omawia wplyw rozwarstwienia łopat nośnych śmigtowca na zmiany pola temperatur oraz pojemności elektrycznej pomiędzy dźwigarem a elementem grzejnym. Podczas demontażu sekcji grzejnych topat wirnika nośnego stwierdzono liczne lokalne odklejenia taśmy elementu grzejnego od struktury pakietu grzejnego topaty. Miejsce takiego odklejenia jest potencjalnym rejonem lokalnego zwiększania temperatury zarówno elektrycznego elementu grzejnego, jak $i$ struktury mechanicznej samej łopaty. Przegrzane struktury kompozytowe odznaczaja się mniejsza elastycznościa i staja się podatne na pękanie. Dlatego możliwość bezinwazyjnego monitorowania rozklejenia warstw kompozytowych bez demontażu topaty bytaby dla nich szczególnie przydatna.

Stowa kluczowe: rozwarstwienie kompozytowych topat śmigłowców, sekcje grzejne topat, ogrzewanie przeciwoblodzeniowe, izolacja pakietów grzewczych topaty, pojemność elektryczna izolacji. 
Termovision and electricity capacitance measurements as a evaluation of a helicopter... Ocena rozwarstwienia topat wirników śmigłowców na podstawie pomiarów...

\section{Wprowadzenie}

Oblodzenie śmigłowca jest zjawiskiem niebezpiecznym, ponieważ zmienia charakterystyki aerodynamiczne oraz powoduje niewyważenie [3-5, 9] wirników śmigłowca. Najpowszechniejszym skutkiem oblodzenia jest zmiana momentu pochylającego, co powoduje zmianę obciążeń łopat, układu sterowania oraz zwiększenie drgań. Warstwa lodu na profilu łopaty może spowodować przesunięcie jej punktu parcia nawet do $20 \%$ w stosunku do cięciwy [9]. W warunkach intensywnego oblodzenia ewentualne dodatkowe odkształcenie powierzchni spowodowane np. rozwarstwieniem struktury łopaty, zwłaszcza powierzchni w pobliżu krawędzi natarcia, może mieć skutki katastrofalne.

Wraz ze wzrostem oblodzenia sterowność śmigłowca maleje. Jest to spowodowane zmniejszeniem sił nośnych na łopatach wirnika ${ }^{1}$. Na zmniejszenie sterowności ma również wpływ pogorszenie się stateczności śmigłowca spowodowane zmianą wyważenia konstrukcji. Utrzymanie pełnej sterowności w warunkach oblodzenia jest niemożliwe. Oblodzony profil ma mniejszą sprawność aerodynamiczną, a więc mniejszą siłę nośną i zwiększony opór czołowy. Powoduje to odrywanie się warstwy przyściennej strugi opływającej powierzchnię profilu, co zmniejsza siłę nośną. W celu utrzymania zadanej wysokości lotu niedoświadczony pilot zwykle zwiększa kąta natarcia łopat co w tej sytuacji jest błędem. Większe kąty natarcia łopat wymagają większej mocy od silnika, a więc zmniejsza się wówczas zapas mocy. Obniżenie zapasu mocy niesie za sobą zmniejszenie manewrowości śmigłowca. $\mathrm{W}$ tak ciężkich warunkach lotu wszystkie manewry powinny być wykonywane płynnie, bez dynamicznych zmian parametrów pracy układu napędowego oraz wirnika nośnego. $\mathrm{W}$ ten sposób zmniejsza się niebezpieczeństwo zerwania strug powietrza ${ }^{2}$ (co mogłoby skutkować przekroczeniem krytycznego kąta natarcia powodującym skokowe zmniejszenie siły nośnej, czyli tzw. przeciągnięcie) oraz nie dopuszcza się do gwałtownego spadku ciśnienia powietrza w turbosprężarce (co skutkuje równie gwałtownym spadkiem temperatury). Zważywszy na specyfikę sterowania śmigłowca (sterowanie aktywne $[8,12]$ ), każda łopata zmienia kąt natarcia w zależności od swego położenia kątowego, więc zrywanie strug powietrza może występować raz na dłuższym, raz na krótszym wycinku danej łopaty. Tak więc pilot odczuwa to zjawisko w postaci wzrostu wibracji konstrukcji płatowca i elementów sterowania. Obecnie najskuteczniejszym, powszechnie stosowanym na śmigłowcach sposobem zabezpieczenia przed oblodzeniem łopat jest ogrzewanie elektryczne ich krawędzi natarcia przy pomocy elementów grzejnych [2, 6-7].

\footnotetext{
${ }^{1}$ Wirnik nośny śmiglowca stuży nie tylko do wytworzenia sity nośnej, ale także do sterowania katem przechylenia i pochylenia. Jest to możliwe dzięki zastosowaniu tarczy sterującej umożliwiającej chwilowe zwiększanie kątów natarcia topaty [8-9, 11].

${ }^{2} W$ skrajnych przypadkach zerwanie strug powietrza na topatach nośnych może skończyć sie nawet upadkiem śmigłowca.
} 
W warunkach intensywnego obladzania dodatkowe odkształcenie profilu łopaty wirnika nośnego, spowodowane np. jej rozwarstwieniem, może mieć wręcz katastrofalne skutki (fot. 1).

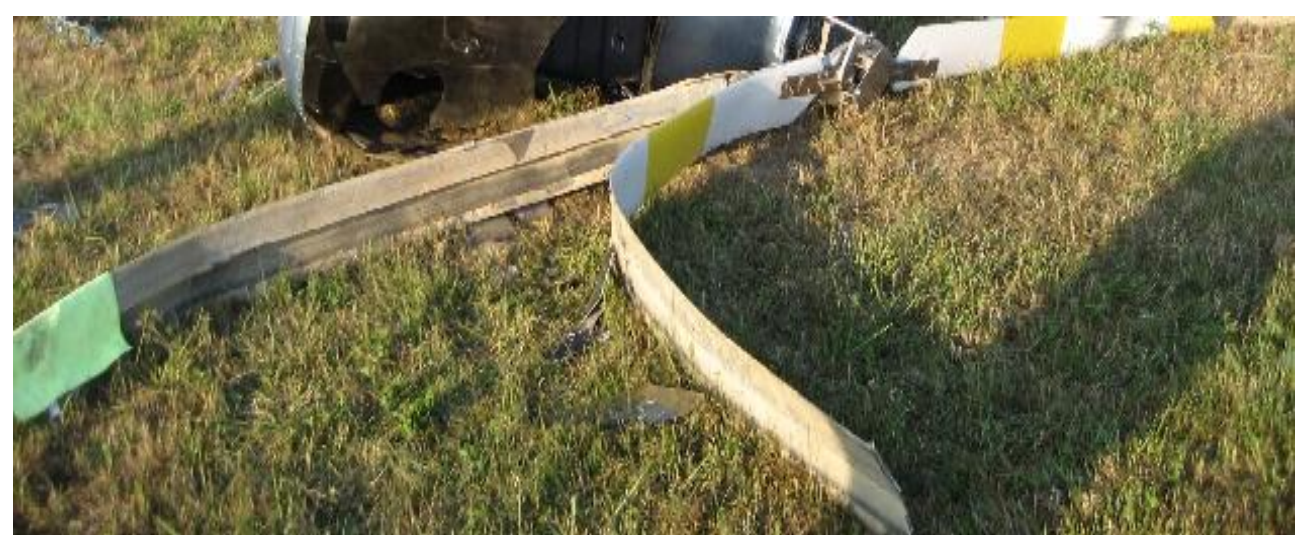

Fot. 1. Rozwarstwienie wykonanej z laminatu topaty wirnika nośnego śmigłowca będace przyczyna ciężkiego wypadku lotniczego

Ponadto rozwarstwienie pomiędzy elementem grzejnym łopaty a dźwigarem izoluje cieplnie dany odcinek sekcji grzejnej od masy dźwigara. Utworzona w ten sposób poduszka powietrzna jest izolatorem w obwodzie przepływu ciepła. Tworzą się więc odcinki narażone na przegrzanie. W łopatach o strukturze kompozytowej lokalne przegrzania powodują utwardzenie warstw kompozytowych, powodując zmniejszenie jej elastyczności i sprężystości. Takie miejsca są potencjalnymi węzłami pęknięć $[1,10]$. Lokalne przegrzania mogą być miejscem progresywnie rozprzestrzeniającego się rozwarstwienia prowadzącego do ciężkiego wypadku lotniczego.

\section{Możliwość zastosowania pomiarów pojemności elektrycznj sekcji grzejnych do oceny rozwarstwienia lopat śmiglowca}

W czasie badań nad strukturą i właściwościami elementów grzejnych łopat nośnych w ITWL wykonano pomiary pojemności elektrycznej:

- między dźwigarem a elementami grzejnymi łopat dla śmigłowców Mi-8 i Mi-17;

- między elementami grzejnymi łopat a warstwą siatki metalowej dla śmigłowca W-3.

Dokonano także kontrolowanego rozwarstwienia jednej z łopat śmigłowców Mi-8 i Mi-17, tworząc pomiędzy segmentem grzejnym a dźwigarem łopaty szczelinę powietrzną o szerokości $d=1 \mathrm{~mm}$ i o różnych długościach. Na rys. 1 numerami 5, 6, 17 oznaczone zostały sekcje spływowe łopaty, na których szerokości wykonano rozwarstwienie po stronie krawędzi natarcia łopaty. Czerwonym kolorem zostały zaznaczone i zwymiarowane elementy sekcji grzejnej łopaty odwarstwione od dźwigara. Wymiar $7600 \mathrm{~mm}$ oznacza całkowitą długość sekcji grzejnych. 
Termovision and electricity capacitance measurements as a evaluation of a helicopter... Ocena rozwarstwienia topat wirników śmigłowców na podstawie pomiarów...

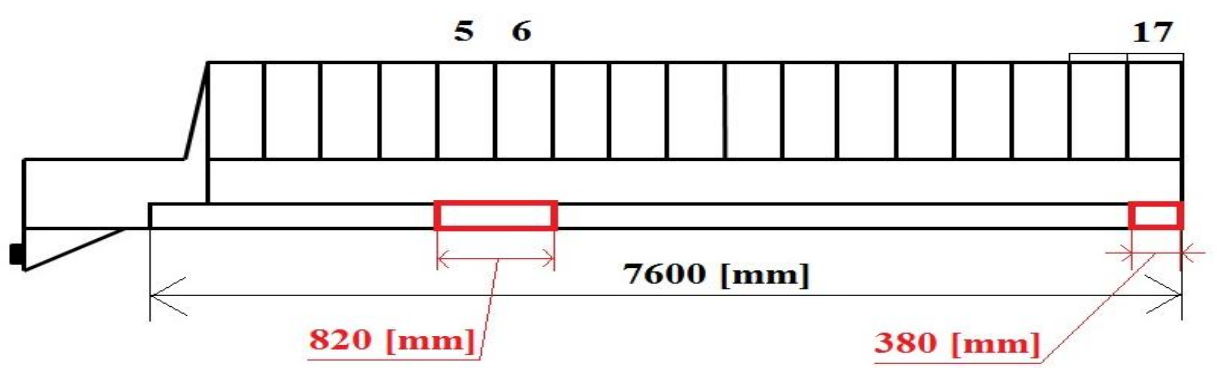

Rys. 1. Poglądowy rysunek topaty dla śmigłowców Mi-8 i Mi-17

$\mathrm{Na}$ rys. 2 przedstawiono profil łopaty nośnej śmigłowców Mi-8 i Mi-17 z oznaczonymi sekcjami grzejnymi oraz dźwigarem łopaty występującym przy pomiarze pojemności elektrycznej.

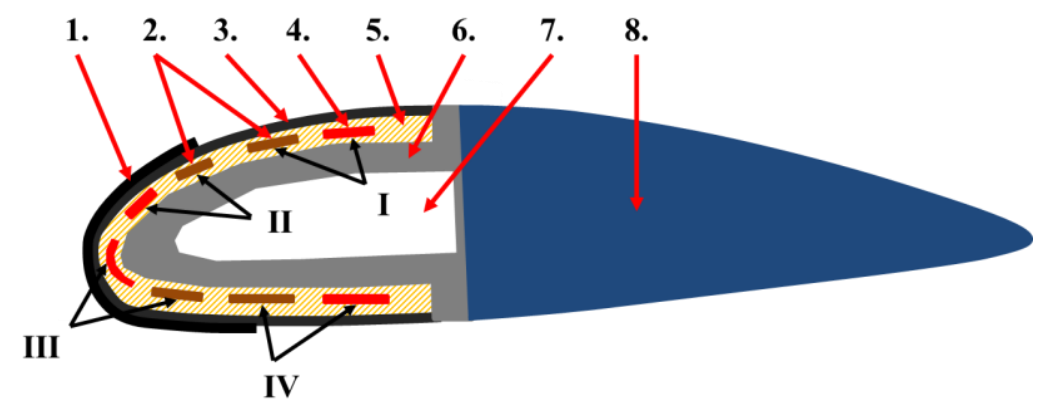

Rys. 2. Pogladdowy rysunek profilu topaty śmigłowców Mi-8 i Mi-17

Oznaczenia: 1 -okucie ze stali nierdzewnej; 2 - taśmy powrotne sekcji grzejnych; 3 - gumowa ostona; 4 - taśmy oporowe sekcji grzejnych; 5 - warstwy włókna szklanego tworzace pakiet izolacyjny; 6 - dźwigar topaty; 7 - pusta przestrzeń wewnatrz dźwigara; 8 - sekcja splywu z wypetniaczem ulowym; I, II, III, IVnumery sekcji grzejnych.

Do pomiarów pojemności elektrycznej zastosowano układ przedstawiony na rys. 3 .

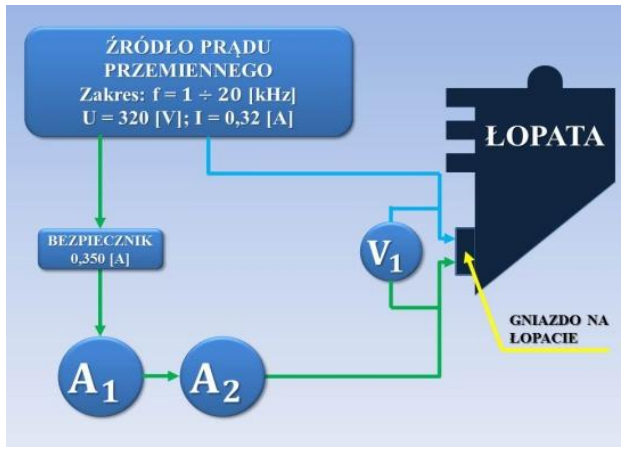

Rys. 3. Schemat pogladowy układu do pomiaru pojemności elektrycznej (metoda techniczna) 
Wyniki pomiarów pojemności elektrycznej dla zadanych rozwarstwień łopaty (o całkowitej długości szczeliny: $L=380 \mathrm{~mm}$ oraz $L=1400 \mathrm{~mm}$ ) przedstawiono w tabeli 1.

Tabela 1. Wartości zmierzonej pojemności elektrycznej pomiędzy elementem grzejnym topaty a dźwigarem dla poszczególnych sekcji grzejnych instalacji przeciwoblodzeniowej jednej z łopat wirnika nośnego śmigłowców Mi-8 i Mi-17.

\begin{tabular}{|c|c|c|c|c|c|c|c|}
\hline \multirow{3}{*}{ Lp } & \multirow{3}{*}{$\begin{array}{c}\text { Numer sekcji } \\
\text { grzejnej (nr } \\
\text { pomiarowy } \\
\text { kołka złącza } \\
\text { elektrycznego } \\
\text { kolektora } \\
\text { instalacji } \\
\text { grzewczej } \\
\text { łopaty nośnej) }\end{array}$} & \multicolumn{6}{|c|}{ Pomiary wykonano dla częstotliwości z zakresu $8 \div 12[\mathrm{kHz}]$} \\
\hline & & \multicolumn{6}{|c|}{$\begin{array}{l}\text { Wartości średnie pojemności elektrycznej pomiędzy taśmą (grzejną } \\
\text { lub powrotną) a masą dźwigara łopaty nośnej śmigłowca }\end{array}$} \\
\hline & & \begin{tabular}{|c|}
$C_{1}[F]$ \\
przed \\
rozwarstwieniem
\end{tabular} & $\begin{array}{c}\left(C_{1}-C_{2}\right) / C_{1} \\
{[\%]} \\
\text { różnica } \\
\text { wzzlędna } \\
\end{array}$ & \begin{tabular}{c|}
$C_{2}[F]$ po \\
rozwarstwieniu \\
o długości \\
$\mathrm{L}=380 \mathrm{~mm}$ \\
\end{tabular} & \begin{tabular}{|c|}
$\left(C_{2}-\mathrm{C}_{3}\right) / C_{2}$ \\
{$[\%]$} \\
różnica \\
względna \\
\end{tabular} & \begin{tabular}{|c|}
$C_{3}[F]$ po \\
rozwarstwieniu \\
o długości \\
$L=1400 \mathrm{~mm}$ \\
\end{tabular} & $\begin{array}{c}\left(C_{1}-\mathrm{C}_{3}\right) / C \\
{[\%]} \\
\text { różnica } \\
\text { względna } \\
\end{array}$ \\
\hline 1 & $\begin{array}{l}\text { Taśma } \\
\text { powrotna } \\
\text { sekcji } \\
\text { grzejnych } \\
\text { I, II, III i IV } \\
\text { (13 pin) }\end{array}$ & $3,24 \mathrm{E}-08$ & 3 & $3,14 \mathrm{E}-08$ & 6 & 2,94E-08 & 9 \\
\hline 2 & $\begin{array}{c}\text { Taśma } \\
\text { oporowa } \\
\text { sekcji } \\
\text { grzejnej I } \\
(12 \text { pin })\end{array}$ & $8,24 \mathrm{E}-08$ & 53 & $3,88 \mathrm{E}-08$ & 79 & $8,00 \mathrm{E}-09$ & 90 \\
\hline 3 & $\begin{array}{c}\text { Taśma } \\
\text { grzejna } \\
\text { sekcji } \\
\text { grzejnych II } \\
\text { (11 pin) } \\
\end{array}$ & $3,29 \mathrm{E}-08$ & 6 & $3,10 \mathrm{E}-08$ & 8 & $2,84 \mathrm{E}-08$ & 14 \\
\hline 4 & $\begin{array}{c}\text { Taśma } \\
\text { grzejna } \\
\text { sekcji grzej } \\
\text { nych III } \\
\text { (7 pin) } \\
\end{array}$ & $1,58 \mathrm{E}-08$ & 4 & $1,52 \mathrm{E}-08$ & 5 & $1,44 \mathrm{E}-08$ & 9 \\
\hline 5 & $\begin{array}{c}\text { Taśma } \\
\text { grzejna } \\
\text { sekcji grzej } \\
\text { nych IV } \\
(5 \text { pin }) \\
\end{array}$ & $1,68 \mathrm{E}-08$ & 52 & $8,08 \mathrm{E}-09$ & 70 & 2,44E-09 & 85 \\
\hline
\end{tabular}

Na bazie analizy otrzymanych wyników pomiarów, wykonanych w trzech etapach (bez rozwarstwienia, po rozwarstwieniu o długości $L=380 \mathrm{~mm}$ oraz o długości $L=1400 \mathrm{~mm}$ ), stwierdzono znaczne zmniejszenie wartości mierzonej pojemności elektrycznej, wprost proporcjonalne do powierzchni rozwarstwienia. 
Termovision and electricity capacitance measurements as a evaluation of a helicopter... Ocena rozwarstwienia topat wirników śmigłowców na podstawie pomiarów...

Stwierdzono, że wartość pojemności elektrycznej dla kondensatora utworzonego przez dwie taśmy grzejne wybranej sekcji i dźwigar łopaty można opisać w postaci zależności:

$$
C=\varepsilon_{0} \cdot \varepsilon_{r} \cdot \frac{S}{d}
$$

gdzie:

$\varepsilon_{0}-$ współczynnik przenikalności elektrycznej próżni [F/m];

$\varepsilon_{r}$ - współczynnik przenikalności elektrycznej charakterystyczny dla danego materiału izolacyjnego umieszczonego pomiędzy okładzinami kondensatora $[\mathrm{F} / \mathrm{m}]$;

$S$ - pole powierzchni jednej czynnej okładziny kondensatora utworzonego przez dwie taśmy grzejne i dźwigar łopaty $\left[\mathrm{m}^{2}\right]$;

$d$ - szerokość szczeliny powietrznej między okładzinami kondensatora określona jako odległość między taśmami elementów grzejnych a dźwigarem łopaty [m].

Wartości pojemności elektrycznej kondensatora utworzonego przez dwie taśmy grzejne wybranej sekcji a dźwigarem łopaty dla zadanych wartości rozwarstwienia, obliczone na podstawie zależności (1), zestawione zostały w tabeli 2.

Tabela 2. Wartości obliczonej pojemności elektrycznej pomiędzy elementem grzejnym a dźwigarem dla rozwarstwionej topaty śmigłowców Mi-8 i Mi-17

\begin{tabular}{|l|c|c|}
\hline \multicolumn{1}{|c|}{ Pojemność elektryczna } & $\begin{array}{c}\text { Wartości } \\
\text { pojemności elektrycznej } \\
\text { po rozwarstwieniu } \\
{[\mathrm{F}]}\end{array}$ & $\begin{array}{c}\text { Zmniejszenie wartości } \\
\text { pojemności po } \\
\text { rozwarstwieniu } \\
{[\%]}\end{array}$ \\
\hline $\mathrm{C}_{1}-$ bez wady rozwarstwienia & $9,69114 \mathrm{E}-09$ & - \\
\hline $\mathrm{C}_{2}-$ rozwarstwienie $L=380 \mathrm{~mm}$ & $9,44886 \mathrm{E}-09$ & 3 \\
\hline $\mathrm{C}_{3}-$ rozwarstwienie $L=1400 \mathrm{~mm}$ & $8,79854 \mathrm{E}-09$ & 9 \\
\hline
\end{tabular}

Z porównania wartości obliczonych teoretycznie (tabela 2) z wartościami zmierzonymi (tabela 1) pojawia się zauważalna różnica, wynikająca z nieuwzględnienia fizykalnych czynników wpływających na pojemność elektryczną izolacji (rzeczywisty wymiar powierzchni oddziałujących elektrycznie na siebie, poziom wilgotności materiału izolacyjnego, rzeczywista odległość pomiędzy taśmą sekcji grzejnej a dźwigarem wzdłuż całej łopaty, temperatura izolacji itp.). Czynniki te nie zostały uwzględnione w celu uproszczenia obliczeń teoretycznych.

Na rys. 4 zestawiono wartości średnie pojemności elektrycznej zmierzonej między dźwigarem a taśmą oporową każdej sekcji grzewczej instalacji przeciwoblodzeniowej łopaty śmigłowców Mi-8 i Mi-17. Kolorami: niebieskim (wykres górny), czerwonym (wykres środkowy) i zielonym (wykres dolny) zostały oznaczone kolejne etapy zwiększana długości rozwarstwienia łopaty (zwiększanie długości szczeliny powietrznej pomiędzy taśmą grzejną a dźwigarem). 
Kolor niebieski przedstawia wartości przed rozwarstwieniem, czerwony po wprowadzeniu małego rozwarstwienia o długości $L=380 \mathrm{~mm}$, a zielony - po wprowadzeniu dużego rozwarstwienia o długości $L=1400 \mathrm{~mm}$ i szerokości szczeliny $d=1 \mathrm{~mm}$.

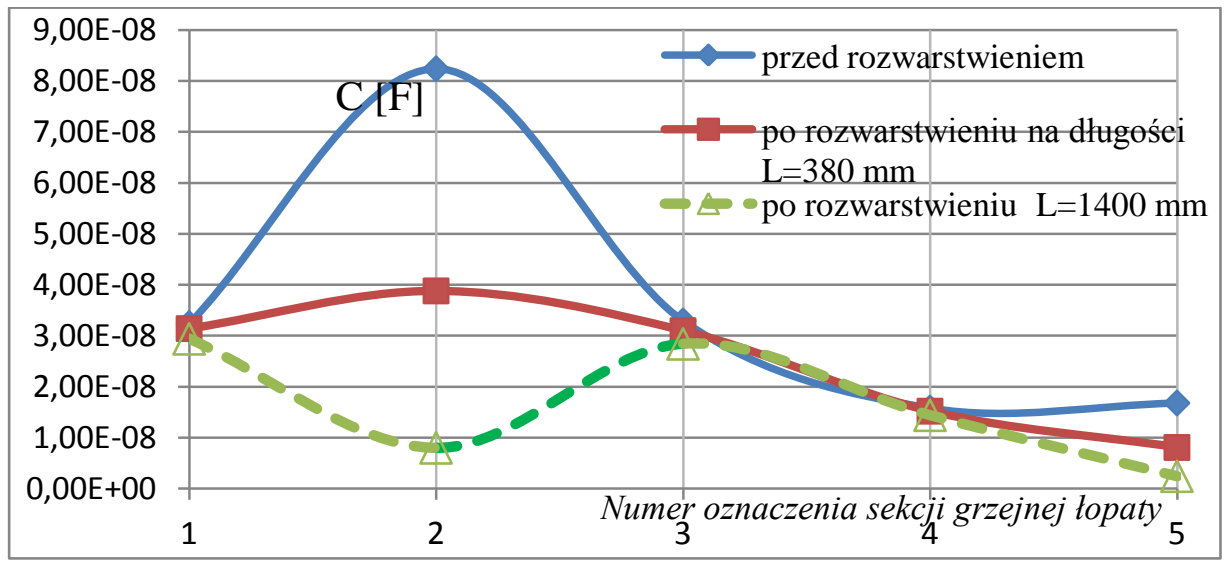

Rys. 4. Zmiany pojemności elektrycznej dla poszczególnych sekcji grzejnych instalacji przeciwoblodzeniowej jednej z topat wirnika nośnego śmigłowców Mi-8 i Mi-17

Można zaobserwować, że wartości pojemności elektrycznej mierzone dla pinów 12 i 5, czyli skrajnych sekcji I i IV (oznaczonych jako 2 i 5 na rys. 4), mają największe zmiany. Spowodowane jest to nierównomiernym odwarstwieniem pakietu izolacyjnego. Podczas rozwarstwienia część pakietu grzewczego w okolicach krawędzi natarcia pozostała przyklejona. Dlatego można zaobserwować zdecydowanie mniejsze różnice wartości pojemności elektrycznej występujące dla sekcji II i III, mierzonej pomiędzy pinami 11 i 7 a dźwigarem łopaty (oznaczonych jako 3 i 4 ).

Na podstawie uzyskanych wyników stwierdzono, że z uwagi na zróżnicowaną geometrię sekcji grzejnych łopat nośnych śmigłowców eksploatowanych w lotnictwie polskim, zróżnicowane są też możliwości lokalizacji geometrii rozwarstwień. Oceniono [10], że metoda ta umożliwiłaby dokładniejszą lokalizację rozwarstwień bardziej na łopatach nośnych śmigłowca W-3 Sokół niż innych śmigłowców m.in. Mi-8 lub Mi-17. Geometrycznie krótsze sekcje grzejne [3], rozciągające się na czterech oddzielnych odcinkach wzdłuż krawędzi natarcia łopaty śmigłowca W-3, umożliwiają dokładną lokalizację rozwarstwień dla stosunkowo małych powierzchni, co może być przydatne w ewentualnym procesie remontowym.

W przypadku łopat nośnych śmigłowców Mi-8 i Mi-17 sekcja grzejna (w postaci taśmy oporowej) rozciąga się na całej długości łopaty, stąd wynika utrudnienie zlokalizowania rozwarstwienia pakietu grzewczego. 
Termovision and electricity capacitance measurements as a evaluation of a helicopter... Ocena rozwarstwienia topat wirników śmigłowców na podstawie pomiarów...

\section{Zastosowanie pomiarów pola temperatur do monitorowania rozwarstwienia lopat}

W ITWL w 2014 r. wykonano pomiary rozkładu temperatur na powierzchni łopaty celem udokumentowania możliwości lokalizacji rozwarstwień pomiędzy taśmą oporową sekcji grzejnej a dźwigarem łopaty nośnej ${ }^{3}$ zabudowanej na śmigłowcach Mi-17 [10]. Pomiary temperatury zostały wykonane przy pomocy dwóch urządzeń - pirometru i kamery termowizyjnej.

Pierwsze badanie (tabela 3 ) polegało na punktowym pomiarze temperatury wzdłuż całej łopaty, która była nieprzerwanie zasilana prądem stałym o stabilizowanym natężeniu ( $I=7 \mathrm{~A})$. Wzdłuż taśmy oporowej IV sekcji grzejnej, na powierzchni gumowej osłony (element 3 na rys. 2) naniesiono równomiernie 5 podwójnych punktów kontrolnych. Do sekcji tej przyłączono zasilacz stabilizowany prądowo. Badania, trwające 2 godziny i 10 minut, rozpoczęto przy napięciu zasilania ${ }^{4}$ zmniejszonym do wartości $U \approx 57 \mathrm{~V}$ (znamionowa wartość tego napięcia wynosi $208 \mathrm{~V})$.

Tabela 3. Wartości zmierzonej temperatury na powierzchni topaty nośnej śmigłowców Mi-8 i Mi-17 w miejscu zasilanej IV sekcji grzejnej dla pięciu punktów pomiarowych.

\begin{tabular}{|c|c|c|c|c|c|c|c|c|}
\hline \multirow{2}{*}{$\begin{array}{c}\text { Czas } \\
(\text { LOC })\end{array}$} & \multicolumn{5}{|c|}{$\begin{array}{l}\text { Wybrane punkty pomiarowe na lopacie } \\
\text { i odpowiednio wartości temperatur }\end{array}$} & \multicolumn{3}{|c|}{$\begin{array}{l}\text { Parametry zasilania elektrycznego } \\
\text { i warunki temperaturowe otoczenia }\end{array}$} \\
\hline & 1 & 2 & 3 & 4 & 5 & $U[\mathrm{~V}]$ & $I[\mathrm{~A}]$ & $\begin{array}{c}T_{\text {otoczenia }} \\
{\left[{ }^{\circ} \mathrm{C}\right]}\end{array}$ \\
\hline $19: 30$ & 19,0 & 18,5 & 18,8 & 19,0 & 19,1 & 57,27 & 7 & 18,7 \\
\hline $19: 35$ & 24,8 & 25,5 & 25,2 & 22,6 & 23,5 & 57,27 & 7 & 18,7 \\
\hline $19: 40$ & 24,0 & 24,2 & 23,8 & 21,2 & 21,0 & 57,27 & 7 & 18,7 \\
\hline $19: 45$ & 23,0 & 23,6 & 23,3 & 22,0 & 21,7 & 57,27 & 7 & 18,7 \\
\hline $20: 00$ & 25,7 & 28,0 & 27,4 & 23,6 & 24,0 & 57,27 & 7 & 18,7 \\
\hline $20: 15$ & 28,0 & 28,5 & 30,0 & 26,5 & 26,2 & 57,33 & 7 & 16,8 \\
\hline $20: 30$ & 30,4 & 31,0 & 31,0 & 27,7 & 25,7 & 57,37 & 7 & 16,8 \\
\hline $20: 45$ & 29,6 & 33,1 & 33,0 & 30,4 & 29,3 & 57,38 & 7 & 16,6 \\
\hline 21:00 & 30,9 & 32,8 & 32,5 & 28,0 & 26,5 & 57,40 & 7 & 16,5 \\
\hline $21: 40$ & 30,5 & 32,0 & 32,7 & 30,3 & 28,0 & 57,39 & 7 & 16,0 \\
\hline
\end{tabular}

Wyniki pomiaru temperatury na powierzchni łopaty nośnej dla śmigłowców Mi-8 i Mi-17 w miejscu zasilanej IV sekcji grzejnej w pięciu punktach pomiarowych przedstawiono na rys. 5 .

${ }^{3}$ Łopata nośna śmigłowca Mi-17 jest w petni zamienna z łopata nośna śmigłowca Mi-8.

${ }^{4}$ Napięcie zasilania dla zasilacza o stabilizowanej wartości natężenia prądu $(I=7 \mathrm{~A})$ ulega automatycznemu zwiększeniu wraz ze wzrostem wartości rezystancji taśmy oporowej sekcji grzejnej w czasie jej nagrzewania. 


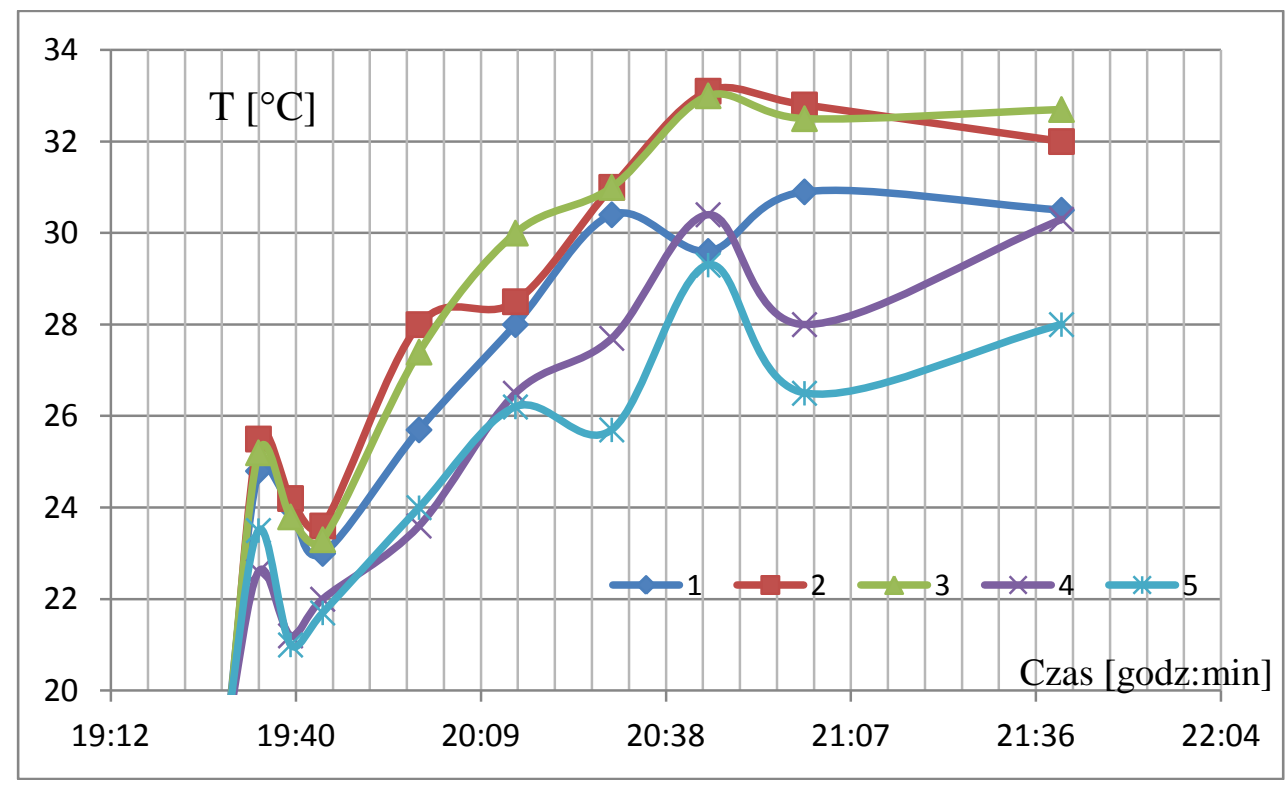

Rys. 5. Wartości temperatury na powierzchni łopaty nośnej dla śmigłowców Mi-8 i Mi-17 w miejscu zasilanej IV sekcji grzejnej w pięciu punktach pomiarowych

Druga metoda pomiarowa, wykorzystująca kamerę termowizyjną do pomiarów pola temperatur, miała na celu zbadanie, czy i w których miejscach na łopacie występują lokalne różnice temperatur, zwłaszcza w obszarach zabudowania sekcji grzewczych. W tym celu na łopacie zostały wybrane punkty pomiarowe (Sp1, Sp2, Sp3 - oznaczone krzyżykiem na fot. 2 i fot. 3) dla zasilanej IV sekcji grzewczej, znajdującej się w dolnej części łopaty [10].

Po czasie około 1,5 min od włączenia napięcia zasilania zaobserwowano pierwsze zróżnicowanie temperatury wzdłuż łopaty, które pogłębiało się wraz z czasem trwania ogrzewania łopaty (na fot. 2 pewne punkty mają znacząco wyższą temperaturę od pozostałych).

Następnie stwierdzono, że po odłączeniu zasilania punkty te wolniej stygły w stosunku do pozostałych (fot. 3). Można je zlokalizować w zaznaczonym punkcie Sp3, gdzie widoczny jest obszar o temperaturze znacząco wyższej od sąsiednich punktów Sp1 i Sp2.

Oceniono, że najprawdopodobniej w tych miejscach występują lokalne rozklejenia. Rozklejenia te mogą być wypełnione powietrzem, które działa jak izolator termiczny, z tego powodu dużo wolniej się chłodzą. Miejsca te mogą być także potencjalnym rejonem przepaleń oraz zarodkiem progresywnego procesu rozwarstwiania się łopaty. 
Termovision and electricity capacitance measurements as a evaluation of a helicopter... Ocena rozwarstwienia topat wirników śmigłowców na podstawie pomiarów...

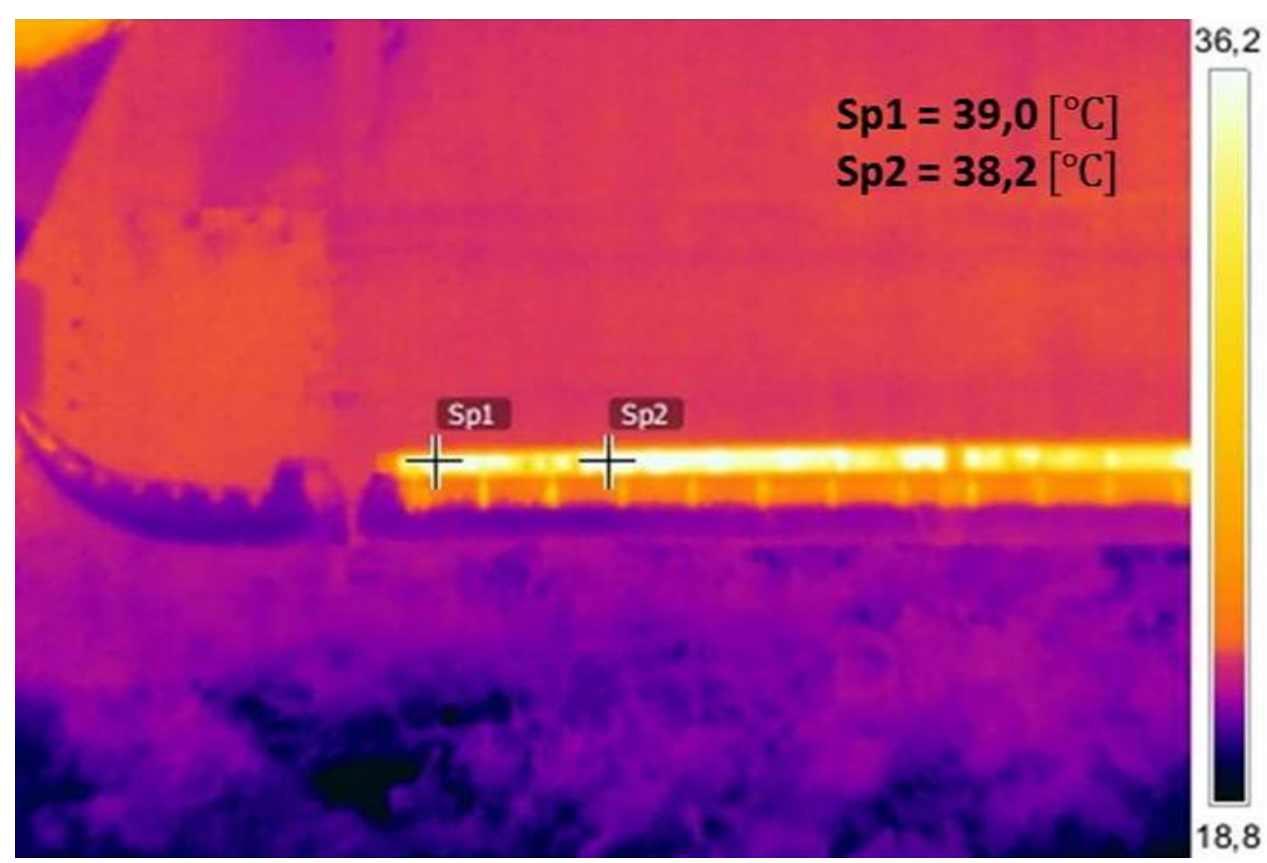

Fot. 2. Badania termowizyjne IV sekcji grzewczej na łopacie śmigłowców Mi-8 i Mi-17. Końcowa część łopaty. Początek grzania (po właczeniu zasilania)

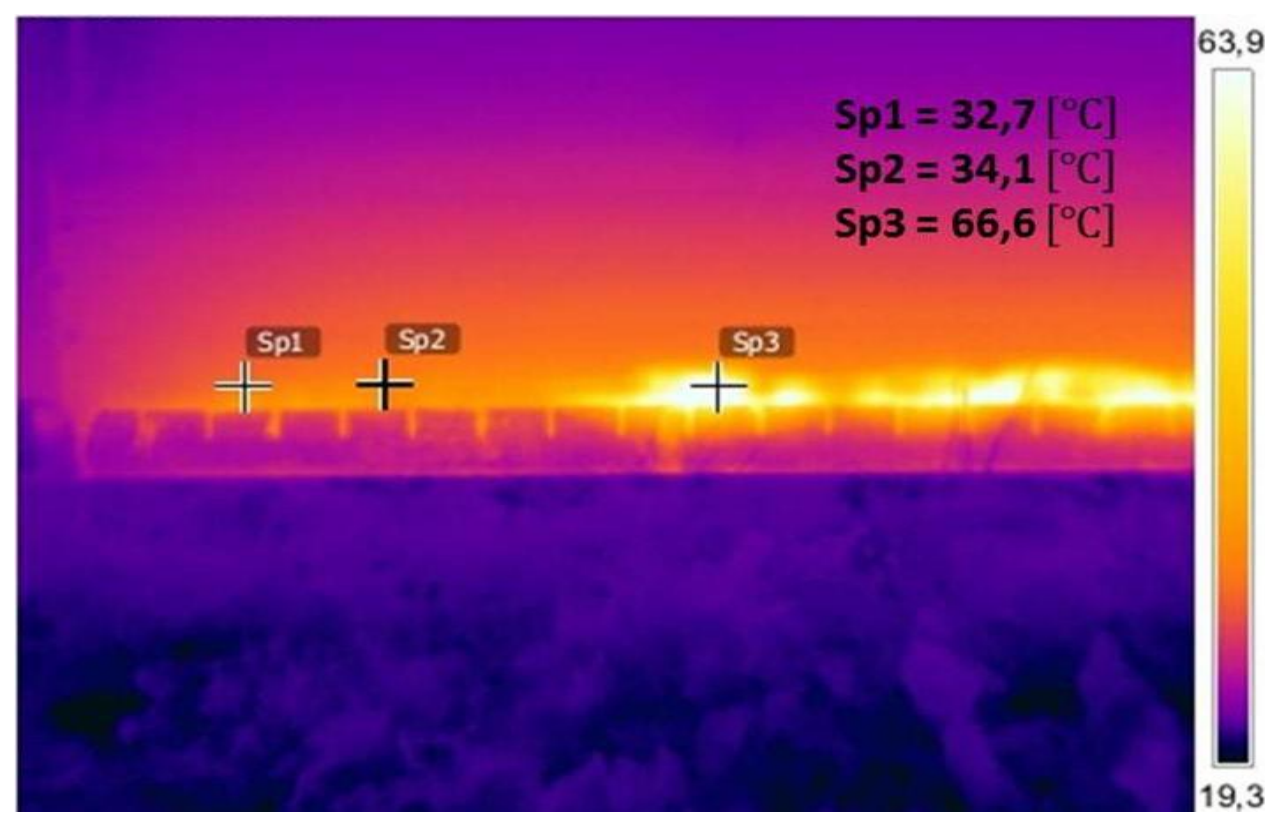

Fot. 3. Badania termowizyjne IV sekcji grzewczej na łopacie śmigłowców Mi-8 i Mi-17. Końcowa część łopaty. Chłodzenie (po rozłaczeniu obwodu pradowego) 

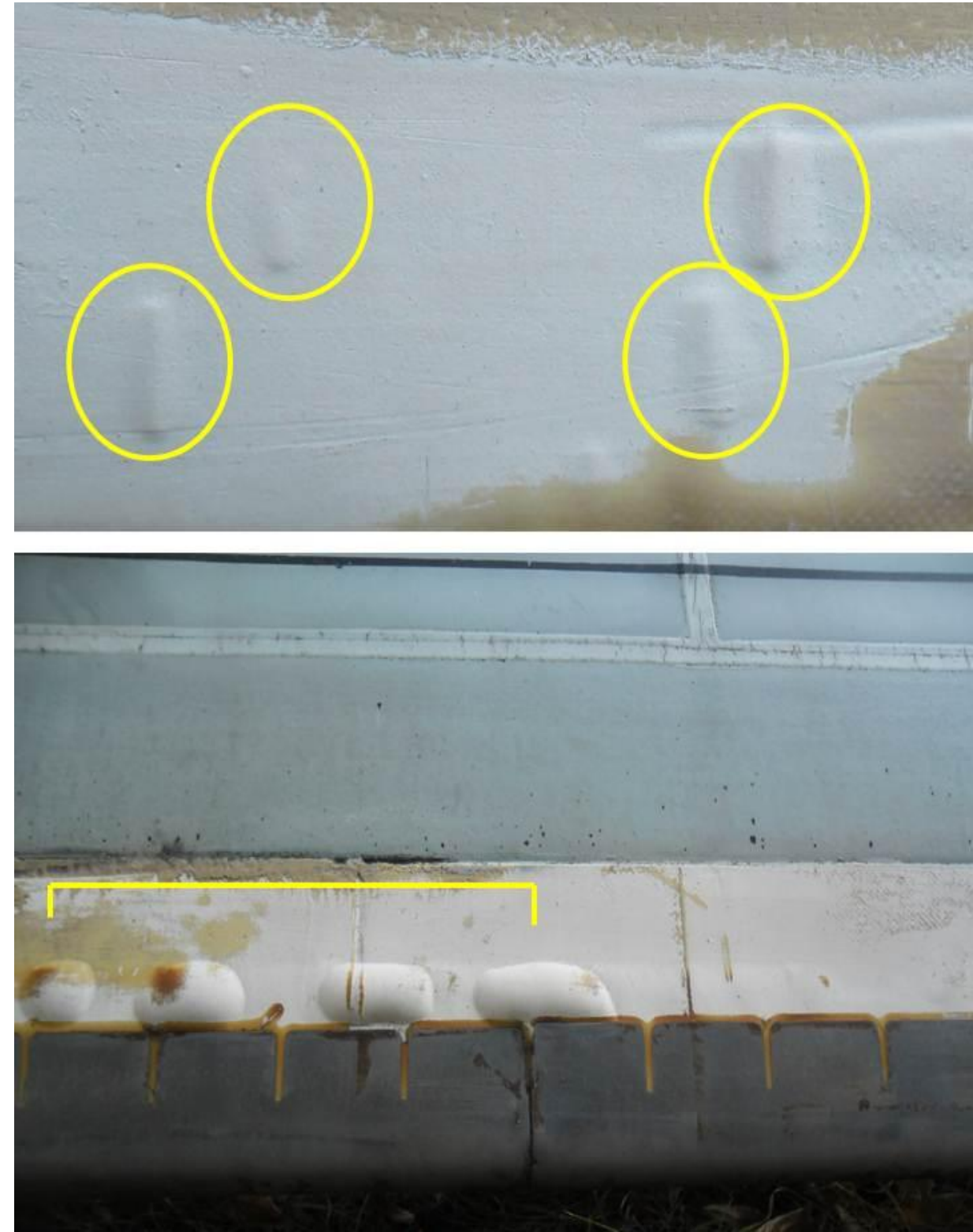

Fot. 4. Miejsca o znacznej różnicy temperatury na łopacie śmigłowców $\mathrm{Mi}-8 \mathrm{i} \mathrm{Mi}-17$

Szczegółowe badania powłoki łopaty wykonane w ITWL wykazały, że określone w badaniach termowizyjnych miejsca rozwarstwienia pomiędzy dźwigarem a elementem grzejnym łopaty stanowią otoczkę powietrzno-izolacyjną wokół taśmy grzewczej, powodując lokalne zmniejszenie intensywności odprowadzenia ciepła (na fot. 4 miejsca te zostały oznaczone okręgami w kolorze żółtym). 
Termovision and electricity capacitance measurements as a evaluation of a helicopter... Ocena rozwarstwienia topat wirników śmigłowców na podstawie pomiarów...

Skutkuje to zwiększeniem temperatury elementu grzejnego podczas zasilania prądem elektrycznym oraz znacznym opóźnieniem procesu chłodzenia po rozłączeniu obwodu prądowego.

W czasie oględzin stwierdzono także, że odcinek taśmy grzejnej o wyższej temperaturze (oznaczony jako żółta klamra na fot. 4) był odklejony od pakietu izolacyjnego oraz od dźwigara badanej łopaty. Takie rozklejenie może być szczególnie niebezpieczne w łopatach o dźwigarze laminatowym, gdzie miejsca przegrzania mogą powodować niekorzystną zmianę właściwości wytrzymałościowych kompozytu $[1,11]$.

\section{Podsumowanie}

Oblodzenie łopat śmigłowca, zmieniając kształt profilu nośnego, może się przyczynić do pogorszenia właściwości aerodynamicznych łopaty. Może to powodować dodatkowe miejscowe zawirowania i oderwania strug powietrza, co zazwyczaj dodatkowo sprzyja intensywności oblodzenia w tych miejscach. Podczas lotu śmigłowca w warunkach oblodzenia powierzchnia oderwania strug w górnej części profilu łopaty zwiększa się, a więc zmniejsza się siła nośna. Zwykle niedoświadczony pilot zwiększa wówczas kąt natarcia łopat w celu utrzymania zadanej wysokości lotu. Często przy szybkim nawarstwianiu się lodu takie zwiększenie kąta natarcia wykonywane jest w szybkim tempie. Jest to dużym błędem, gdyż zwiększa się wówczas powierzchnia oderwania strug w górnej części profilu łopaty i spada siła nośna. Po przekroczeniu wartości krytycznego kąta natarcia siła nośna może zmniejszyć się gwałtownie, co powoduje utratę sterowności i szybkie opadanie śmigłowca. Aby do tego nie dopuścić, po stwierdzeniu oblodzenia pilot powinien płynnie i powoli zmieniać kąt natarcia.

Bezinwazyjne badania wielkości rozwarstwienia łopat, oparte na pomiarze pojemności elektrycznej i termowizji wybranych sekcji grzewczych łopat, mogą wspomagać ich diagnozowanie podczas obsług technicznych śmigłowców W-3 oraz Mi-8 i Mi-7. Wcześniejsze wykrywanie i ocena rozległości tych rozwarstwień umożliwia podjęcie skutecznych środków zaradczych (naprawa, ograniczenia eksploatacyjne). Wprowadzenie do eksploatacji tych dwóch metod może oddać nieocenione usługi na rzecz bezpieczeństwa lotów, w szczególności dla śmigłowców z łopatami kompozytowymi. Rozwarstwienie pomiędzy konstrukcją nośną łopaty a elementem grzejnym jest spotykane w praktyce eksploatacyjnej i w początkowym okresie jest trudne do wykrycia tradycyjnymi metodami. Ponadto stosowane dotychczas metody wymagają demontażu łopat co w warunkach intensywnych lotów jest trudne do zaakceptowania.

Przedstawione metody techniczne pomiaru pojemności elektrycznej (pomiędzy sekcją grzewczą a dźwigarem) oraz pomiaru rozkładu temperatury na powierzchni 
łopaty przy pomocy kamery termowizyjnej i pirometru umożliwiają badanie rozwarstwień bez demontażu łopaty. Zjawisko lokalnego przegrzewania się rejonu łopaty wokół elementu grzejnego jest szczególnie niebezpieczne dla struktur kompozytowych. W czasie przegrzewania poszczególne warstwy kompozytu ulegają sklejeniu, zaś po wystygnięciu odznaczają się mniejszą elastycznością, a więc większą podatnością na mikropęknięcia. Dlatego też dla łopat kompozytowych należałoby zastosować proponowane metody diagnozowania.

Obie te metody wzajemnie mogłyby się uzupełniać, wpływając na podniesienie bezpieczeństwa eksploatacji łopat wirnika nośnego i śmigła ogonowego.

\section{Bibliografia}

[1] Bansemir H., Emmeling S.: Fatigue Substantion And Damage Tolerance Evaluation Of Fiber Composite Helicopter Componets, Eurocopter Deutschland GmbH 81663, ECD-0096-99-PUB, Germany, Munchen 2000.

[2] Będkowski L., Kruś J.: Elektryczność w samolocie, wyd. MON, Warszawa 1965.

[3] Gębura A., Janusiak K., Poradowski M.,2014, Oblodzenie statku powietrznego - przyczyny, skutki, przeciwdziałanie, Journal of KONBiN No 4(32)/2014, Wyd. ITWL, ISSN 1895-8281, ESSN 2083-4608, Warszawa 2014.

[4] Janusiak K.: Latać bezpiecznie, Przegląd Sił Powietrznych Nr 2 (020), ISSN 1897-8444, luty 2009.

[5] Kożuchowski K.: Meteorologia i klimatologia, PWN, Warszawa 2007.

[6] Kulebakin W., Sindejew I., Fiedorow B.: Lotnicze elektryczne urzadzenia zapłonowe, ogrzewcze i oświetleniowe, wyd. MON, 1962.

[7] Kulebakin W., Sindiejew J., Dawidow P., Tiedorow B., Lotnicze elektryczne urzadzenia zaplonowe, ogrzewcze i oświetleniowe, wyd. MON, 1962.

[8] Padfield G., D.: Dynamika lotu śmigłowców. Teoria $i$ wykorzystanie wtaściwości lotnych $i$ modeli symulacyjnych (org. ang. Helicopter Flight Dynamic. The theory and Application of Flying Qualities and Simulation Modeling), WKiŁ, Warszawa 1998.

[9] Poradowski M.: Oblodzenie $i$ jego wptyw na lot śmigłowca. Sposoby zabezpieczenia śmigłowca przed oblodzeniem na podstawie analizy istniejacych i możliwych do zastosowania instalacji przeciwoblodzeniowych, praca inżynierska, Dęblin 2013.

[10] Poradowski M.: Wybrane metody bierne $i$ czynne przeciwdziałania izabezpieczenia oraz wykrywania oblodzenia na śmigłowcach lekkich i średnich - możliwość zapobiegania i zwalczania, praca magisterska, Dęblin 2013. 
Termovision and electricity capacitance measurements as a evaluation of a helicopter... Ocena rozwarstwienia topat wirników śmigłowców na podstawie pomiarów...

[11] Sałaciński M., Synaszko P., Zabłocka M.: Monitorowanie stanu między warstwowych sklein lotniczych struktur kompozytowych $w$ trakcie eksploatacji i po naprawie zgodnie z filozofia damagetolerance, 40 Krajowa Konferencja Badań Nieniszczących, Warszawa 2011.

[12] Żurek J., Praca zbiorowa: Żywotność śmiglowców, ISBN 83-7204-555-0, Warszawa 2006.

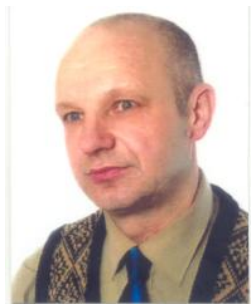

dr inz. Andrzej Gębura - absolwent Wojskowej Akademii Technicznej na kierunku elektromechanika, specjalność: osprzęt lotniczy. W $1998 r$. obronit rozprawe doktorska $w$ Instytucie Technicznym Wojsk Lotniczych. Trzykrotnie wykonywat obowiazki stużbowe w Iraku i raz w Afganistanie.

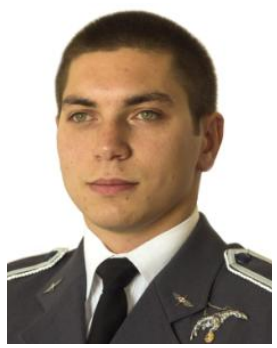

mgr inż. Michat Poradowski - absolwent Wyższej Szkoty Oficerskiej Sit Powietrznych w Dęblinie na wydziale Lotnictwo $i$ Kosmonautyka, specjalność: Pilot śmigłowca. $W$ działalności naukowej specjalizuje się $w$ problematyce bezpieczeństwa lotów, głównie $w$ metodach przeciwdziałania $i$ zabezpieczania oraz wykrywania oblodzenia na śmigłowcach lekkich $i$ średnich. 